Abstract-The Penobscot River is home to the last remaining major run of Atlantic salmon (Salmo salar) in the United States and the subject of a century-long stocking effort. Since the 1970s, most kelts have been released to the estuary after they spawn in a hatchery, and the iteroparous share of the run has declined to $<1 \%$. We tagged with a radio transmitter 55 kelts that had spawned at a hatchery in 2015 , and released them at two locations (head of tide and $\sim 50 \mathrm{~km}$ upstream) to assess 1) when kelts leave the river, 2) whether release location influences the timing of river exit, and 3) whether kelts from the upper river could outmigrate through the hydroelectric complex of the river. The kelts were tracked from November 2015 to July 2016. Although fish from both release groups left the system within one month, the majority $(84 \%)$ overwintered in freshwater. Many (71\%) kelts that overwintered in freshwater made upstream movements in November and December. There was no difference in upstream movement rates, timing of outmigration, or survival between the release groups. Survival to outmigration was $23.6 \%$. This low survival to outmigration may have contributed to the precipitous decline in iteroparous Atlantic salmon from the Penobscot River over the last four decades.

Manuscript submitted 8 March 2018. Manuscript accepted 28 June 2018. Fish. Bull. 116:281-290 (2018). Online publication date: 20 July 2018. doi: 10.7755/FB.116.3-4.6

The views and opinions expressed or implied in this article are those of the author (or authors) and do not necessarily reflect the position of the National Marine Fisheries Service, NOAA.

\title{
Movement and mortality of Atlantic salmon kelts (Salmo salar) released into the Penobscot River, Maine
}

\author{
George A. Maynard (contact author) 1 \\ Lisa K. Izzo' \\ Joseph D. Zydlewski ${ }^{1,2}$ \\ Email address for contact author: galphonsemaynard@gmail.com \\ ${ }^{1}$ Department of Wildlife, Fisheries, and Conservation Biology \\ University of Maine \\ 5755 Nutting Hall, Room 210 \\ Orono, Maine 04469-5755 \\ Present address for contact author: Cape Cod Commercial Fishermen's Alliance \\ 1566 Main Street \\ Chatham, Massachusetts 02633 \\ 2 U.S. Geological Survey \\ Maine Cooperative Fish and Wildlife Research Unit \\ 5755 Nutting Hall, Room 210 \\ University of Maine \\ Orono, Maine 04469-5755
}

Atlantic salmon (Salmo salar) populations in the United States have declined precipitously over the last several decades, and the only remaining population segment is listed as endangered under the U.S. Endangered Species Act (Fay et al., 2006). The Penobscot River historically supported spawning runs of more than 100,000 individuals (Saunders et al., 2006), but recent returns have averaged only around 1000 fish annually $\left(\mathrm{Cox}^{1}\right)$. The U.S. Government has identified restoration of the distinct population segment of the Gulf of Maine as a high priority (NMFS and USFWS, 2005). However, Atlantic salmon face a variety of threats because of their anadromous and iteroparous life history (Legault, 2005; Maynard et al., 2017), such as overfishing, pollution, and the presence of dams (Parrish et al., 1998;

${ }^{1}$ Cox, O. 2016. Personal commun. Maine Dep. Mar. Resour., 21 State House Station, Augusta, ME 04333-0021.
Nieland et al., 2015). Although many stages of Atlantic salmon life history have been well studied (Klemetsen et al., 2003), comparatively little is known about the survival and movements of kelts (postspawning adults) after successful spawning. Because repeat spawners have increased reproductive influence in salmonine populations (Kusterle et al., 2013; Trammell et al., 2016), ensuring survival of kelts could enhance restoration efforts.

Many anadromous salmonines can spawn multiple times during their life cycle, returning to sea after each spawning event to recondition (Klemetsen et al., 2003). Survival after spawning can be high in Atlantic salmon ( $80 \%$; Chadwick et al., 1978; Jonsson et al., 1990). However, a much smaller proportion of fish survive to spawn again (Ducharme, 1969). Broadly, the outmigration of kelts takes place in two stages. A small proportion of individuals migrate directly to the sea, whereas the 
majority overwinter in the river before outmigrating to the marine environment during the following spring (Ruggles, 1980). For those fish that overwinter in-river, survival to outmigration is $>50 \%$ (Gray et al., 1987; Downton and Reddin ${ }^{2}$ ). Across systems (North American and European rivers) and species (Atlantic salmon and steelhead, Oncorhynchus mykiss), downstream kelt migrations in spring are generally finished by July (Halttunen et al., 2010; Marston et al., 2012; Lacroix, 2013). Once at sea, the time needed to rebuild energy stores varies according to several factors: the amount of time previously spent in freshwater (Niemelä et al., 2006), migratory distance to marine feeding areas (Lacroix, 2013), and fish condition after spawning (Jonsson et al., 1991).

The ability of kelts to survive 1) a return migration to the sea, 2) a year or more of reconditioning, and 3) a return migration to spawning grounds affects the proportion of repeat spawners, which varies from 0 to $26 \%$ for Atlantic salmon populations (Fleming and Reynolds, 2004; Niemelä et al., 2006). However, spawning runs composed of $>40 \%$ repeat spawners have been reported in undammed systems in Canada that are not subject to commercial exploitation (Jessop, 1976; Saunders and Schom, 1985). The number of broods a fish has is also variable in salmonines. In steelhead, nearly all iteroparous individuals spawn no more than twice in their lifetime (Seamons and Quinn, 2010). Atlantic salmon have been documented as returning for as many as eleven spawning runs during their lives (Ducharme, 1969; Hutchings and Morris, 1985; Saunders and Schom, 1985), but with at-sea kelt survival $<10 \%$ (Jonsson and Jonsson, 2004), multiple returns is likely the exception, rather than the rule.

It is unknown how recent changes to the Penobscot River (Opperman et al., 2011) may have affected migration of naturally spawned kelts from the upper reaches of the river, particularly because the downstream bypasses at all dams are closed for much of the winter, and therefore may not be operational during the postspawning period. Kelts outmigrating down the upper mainstem of the Penobscot River must pass two dams to reach the middle portion of the river (upstream from Milford Dam, and downstream from the Piscataquis River confluence [Fig. 1]), whereas kelts moving through the Piscataquis River must pass three dams to reach the same location. Once reaching the confluence of the Piscataquis and Penobscot rivers, kelts may travel downstream through the main stem of the Penobscot River to the estuary (passing Milford Dam), or migrate through the Stillwater Branch of the river through Gilman Falls Dam, Stillwater Dam, and Orono Dam (Fig. 1).

The Penobscot River has been the focus of hatchery supplementation based on sea-run broodstock since

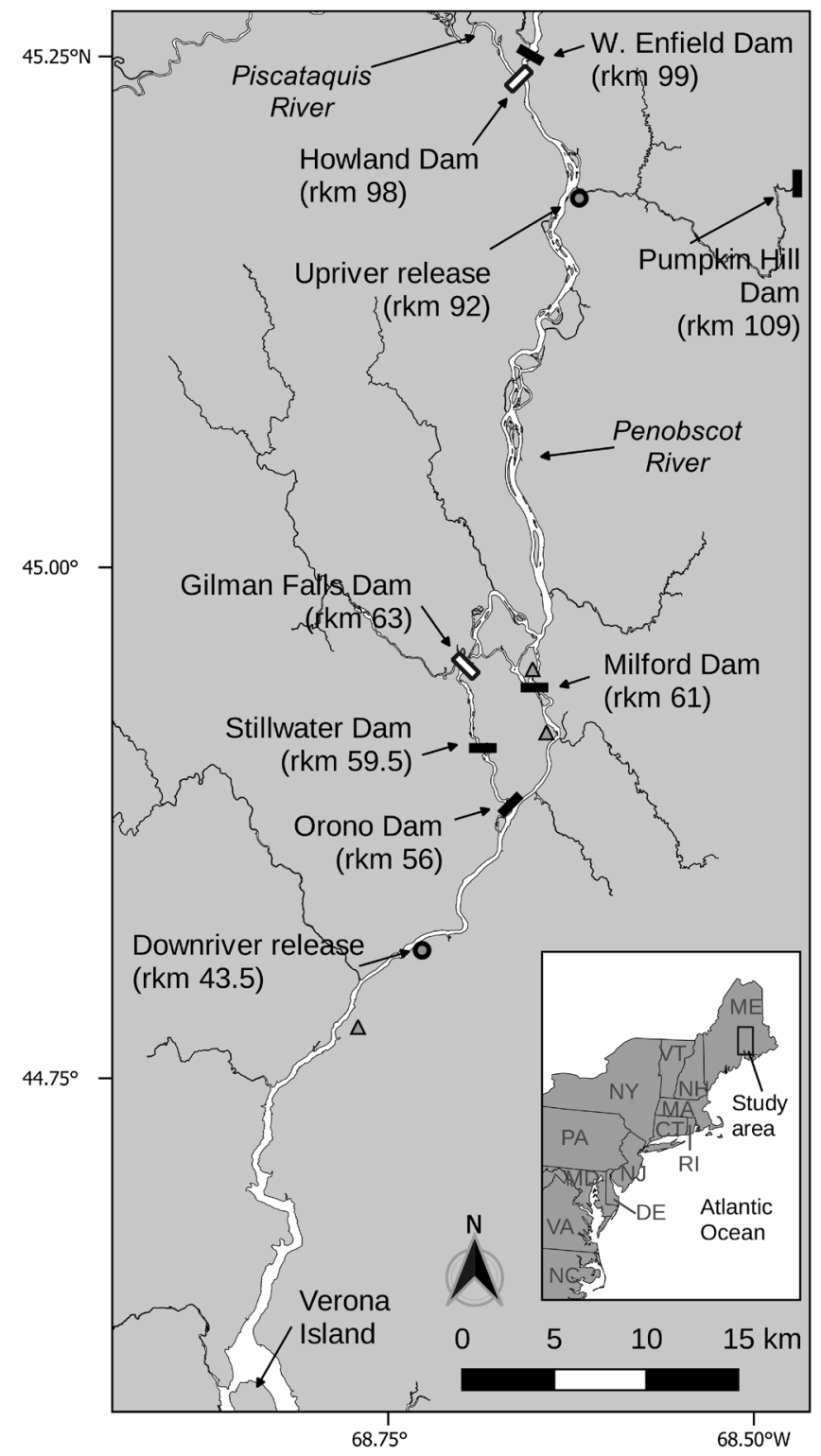

Figure 1

Map of the study area that included the Penobscot River from Orrington, Maine, at river kilometer (rkm) 33, to the West Enfield Dam. Black rectangles represent functioning hydroelectric dams that have no operable fish passage upstream from 15 November to 15 April. Open rectangles represent water control dams that are passable under certain conditions. Gray triangles represent the locations of stationary radio receivers, and circles indicate the sites where tagged kelt Atlantic salmon (Salmo salar) were released on 17 November 2015. River kilometer zero is located at the southwestern tip of Verona Island (516414E 4927755N, UTM Zone 19N). The area surrounded by the Milford, Orono, Stillwater, and Gilman Falls Dams is Marsh Island.

2 Downton, P. R., and D. G. Reddin. 2004. Status of Atlantic salmon (Salmo salar L.) in Campbellton River, Notre Dame Bay (SFA 4), Newfoundland in 2003. Can. Sci. Adv. Secr., Res. Doc. 2004/043, 64 p. [Available from website.] 
the late 1800s (Spidle et al., 2001). Current broodstock management practice requires the collection of mature adults from a trap at the terminus of the first fishway on the river (currently, Milford Dam) by the Maine Department of Marine Resources. These fish are transported to the U.S. Fish and Wildlife Service Craig Brook National Fish Hatchery in Orland, Maine, where they are held for up to five months before spawning is artificially induced in late October or early November. After spawning, kelts are released into the Penobscot River just downstream of the head of tide (at river kilometer [rkm] 43.5). This release point is thought to minimize spatial and temporal overlap with naturally spawning salmon and maximize survival by expediting their return to the sea (Bartron et al. ${ }^{3}$ ); however, neither of these assumptions have been tested. Because of record low returns in 2013 and 2014, 56\% (18-98\%) on average of all salmon returning to the Penobscot River have been taken to the hatchery as broodstock (USASAC ${ }^{4}$ ). Coinciding with decreased returns to the Penobscot River there has been a reduction in the percentage of the run of repeat spawners from an average of $1.7 \%$ in the $1980 \mathrm{~s}$ to an average of $0.6 \%$ in recent years (Maynard et al., 2017).

Although the total number of repeat spawners in the Penobscot River has been low for several decades, their contribution to the total number of eggs produced in the system was likely important, historically. A review of salmon egg production in New England from the early 1980 s to 2011 indicated that, on average, repeat spawners produced 2300 more eggs per female than virgin spawners in the Connecticut River, 3000 more eggs/female in the Sheepscot River, and 3100 more eggs/female in the Merrimack River (USA$\mathrm{SAC}^{3}$ ). Similarly, research from the River Teno, Finland, found that although iteroparous Atlantic salmon numerically represented an average of $5 \%$ of the run, they accounted for an average of $7 \%$ of the total mass of salmon caught in the river (Niemelä et al., 2006). In the river systems of the Pacific Northwest, female iteroparous steelhead have a lifetime reproductive success that is 1.3 times higher than that of semelparous individuals, and iteroparous males have a lifetime reproductive success that is 2.8 times higher than that of semelparous individuals (Seamons and Quinn, 2010), indicating that this life history strategy allows some salmonines to produce more offspring than semelpar-

\footnotetext{
${ }^{3}$ Bartron, M. L., D. Buckley, T. King, M. T. Kinnison, G. Mackey, T. F. Sheehan, K. F. Beland and J. Marancik. 2006. Captive broodstock management plan for Atlantic salmon at Craig Brook National Fish Hatchery, 133 p. Report to the Maine Technical Advisory Committee. [Available from Protected Species Branch, Northeast Fish. Sci. Cent., Natl. Mar. Fish. Serv., NOAA, 166 Water St., Woods Hole, MA 025431026.]

4 USASAC (U.S. Atlantic Salmon Assessment Committee). 2015. Annual report of the U.S. Atlantic Salmon Assessment Committee. Report No. 7-2014 activities. Kittery, Maine, February 9-12, 2015, 228 p. Prepared for U.S. Section to the North Atlantic Salmon Conservation Organization. [Available from website.]
}

ity would. Previously spawned individuals may also provide an important buffer against years with low escapement (Saunders and Schom, 1985) because of their high fidelity to their natal rivers (Hansen and Jonsson, 1994) and high reproductive potential.

Research on kelt movements and survival is relatively sparse, compared with research on other life history stages of salmonines (Hubley et al., 2008). This sparsity of research is especially true in the context of individuals that are artificially induced to spawn at hatcheries. Because nearly all kelts in the Penobscot River system are the product of artificial spawning at hatcheries (i.e. the fish are anesthetized and stripped of gametes before release), a better understanding of postrelease movements may allow a targeted selection of release sites to match the need for suitable overwintering habitat, and therefore improve survival to outmigration.

Our goals were 1) to compare the postrelease movement and exit timing of kelts released at two sites in the Penobscot River, head of tide and upstream of the Marsh Island hydropower complex, which comprises the 4 dams that surround Marsh Island (Milford, Orono, Stillwater, and Gilman Falls), and 2) to evaluate differences in outmigration success between fish released upstream of the hydropower complex and those released downstream, in the free-flowing estuary.

\section{Materials and methods}

\section{Study area}

The Penobscot River, Maine, is the second largest watershed in New England (with an area of 22,000 $\mathrm{km}^{2}$ ) and has been dammed in multiple locations since the late 1800s (Opperman et al., 2011). It also currently has the largest remaining run of Atlantic salmon in the United States and is dependent on hatchery stocking. Since the 1970 s, an average of $82 \%$ of returning adult Atlantic salmon have originated from hatchery-reared smolts $\left(\mathrm{USASAC}^{3}\right.$ ), and in recent years, the number is $>95 \%$.

Our study area (Fig. 1) included a 66-km section of the Penobscot River from Orrington, Maine (rkm 33), to the West Enfield Dam (rkm 99), as well as a $67-\mathrm{km}$ stretch of the Piscataquis River from Howland Dam (rkm 98) to Brown's Mill Dam (rkm 165). There are 8 dams in the study area. Howland Dam has a newly constructed bypass channel that is operational in the winter months. Stillwater Dam and Gilman Falls Dam have no dedicated upstream passage facilities, and the remaining five dams (Orono, Milford, West Enfield, Pumpkin Hill, and Brown's Mill) have upstream passage facilities that are not operated between November 15 and April 15. Downstream passage facilities at Stillwater Dam, Orono Dam, and Milford Dam are closed between December 31 and April 1 because of ice, but passage may still be possible through the spillways or when water overflows the dams. 


\section{Table 1}

Minimum, median, and maximum values of total length $(\mathrm{cm})$, mass $(\mathrm{g})$, and body condition index for kelt Atlantic salmon (Salmo salar) released at an upriver and a downriver site on the Penobscot River, Maine, on 17 November 2015.

\begin{tabular}{lccccccc}
\hline & \multicolumn{3}{c}{ Downriver } & & \multicolumn{3}{c}{ Upriver } \\
\cline { 2 - 3 } \cline { 7 - 8 } & Min & Med & Max & & Min & Med & Max \\
\hline Total length & 72 & 76 & 85 & & 73 & 77 & 81 \\
Mass & 3900 & 4481 & 5901 & & 3338 & 4454 & 5561 \\
Body condition index & -0.03 & 0 & 0.13 & & -0.13 & 0 & 0.16 \\
& & & & & & &
\end{tabular}

\section{Fish capture and tagging}

Throughout the 2015 upstream migration, adult Atlantic salmon were collected at the Milford Dam lift and trap facility (rkm 61) by personnel of the Maine Department of Marine Resources. After collection, the fish were transported to Craig Brook National Fish Hatchery, approximately $56 \mathrm{~km}$ south of the dam, on a different river system. There, fish were held until they spawned in the fall. During the spawning process, fork length, mass, and sex of each fish were recorded. We used the residuals of $\log ($ Mass $)$ regressed on $\log$ (Total length) to calculate body condition (Halttunen et al., 2013). On November 17,2015 , after several days of recovery from the artificial spawning procedure, 55 fish were anaesthetized with tricaine methanosufonate (MS-222) and surgically implanted with MCFT2-3L $\mathrm{L}^{5}$ radio transmitters (Lotek Wireless, Inc., Newmarket, Canada). A 16-mm incision was made offset from the ventral line and posterior to the pelvic fin girdle on the ventral side of the fish to enable closure with two or three sutures of Vicryl size 4-0 (Ethicon, Inc., Somerville, NJ). Tags had an air mass of $25.0 \mathrm{~g}$ and a water mass of $11.0 \mathrm{~g}$, ensuring that they were $<1 \%$ of the estimated body mass of the study fish, which ranged from $3.3 \mathrm{~kg}$ to $5.9 \mathrm{~kg}$ (median mass $=4.4 \mathrm{~kg}$ ). Transmitters had a 2.5 - second burst rate and a tag life of $<170$ days because of their use in a previous study. Of the 55 fish, 27 were released at the boat launch in Brewer, Maine (rkm 43.5, a 26-mile drive from the hatchery), downstream of the head of tide, and 28 were released at the boat launch in Passadumkeag, Maine (rkm 92, an $85 \mathrm{~km}$ drive from the hatchery). All releases took place within five hours of surgery on November 17, 2015.

\section{Radio tracking}

We monitored fish movements over a seven-month period from mid-November 2015 to mid-June 2016, primarily by mobile tracking with a portable receiver (SRX 800, Lotek Wireless, Inc.) during trips in the study

\footnotetext{
5 Mention of trade names or commercial companies is for identification purposes only and does not imply endorsement by the National Marine Fisheries Service, NOAA.
}

area. These trips took place between Orrington (rkm 33) and Medway, Maine (rkm 149), on a weekly basis; more frequent trips (two or three/week) were made before ice-in (late December) and after ice-out (late April). Once a month, we used mobile tracking along the Piscataquis River to detect any fish that moved upstream through the Howland Dam bypass. All mobile tracking was conducted by using cars with omnidirectional antennas traveling along the side of the river on ME-116, U.S. Highway 2, and ME-178 at an average distance of $0.332 \mathrm{~km}(\min 0.037 \mathrm{~km}, \max 0.965 \mathrm{~km})$, and an average speed of $64 \mathrm{~km} / \mathrm{h}$ (40 mph). We also employed an array of three stationary radio receivers (SRX-DL, Lotek Wireless, Inc.) equipped with unidirectional Yagi antennas that were located between Orrington (rkm 33) and Indian Island, Maine (rkm 62; Fig. 1). One aerial survey, conducted aboard an airplane with a portable receiver, covered the mainstem Penobscot River, the Penobscot estuary, and the Piscataquis River on January 25, 2016.

Because a study with similar tagging methods found no tag loss in Atlantic salmon smolts (Stich et al., 2014), we assumed no tag loss. However, fish that remained in the same position throughout the winter, spring, and into the summer of 2016 were presumed dead. We used $\chi^{2}$ tests to test for differences in survival, successful migration, and behavioral differences between the upper and lower release groups. Only fish that were detected at the most downstream receiver or fish that were detected in-river over the duration of the study were included in the survival analysis. Wilcoxon-Mann-Whitney tests were used to compare body condition index between groups of fish with different movements or survival outcomes. For the purposes of this study, we considered overwinter survival to take place between November and late April (ice-out); any movements after this were considered to take place during the spring, and we stopped tracking fish in early July 2016.

\section{Results}

We collected and tagged 55 fish from the hatchery: 53 females and two males (Table 1). All were multiseawin- 


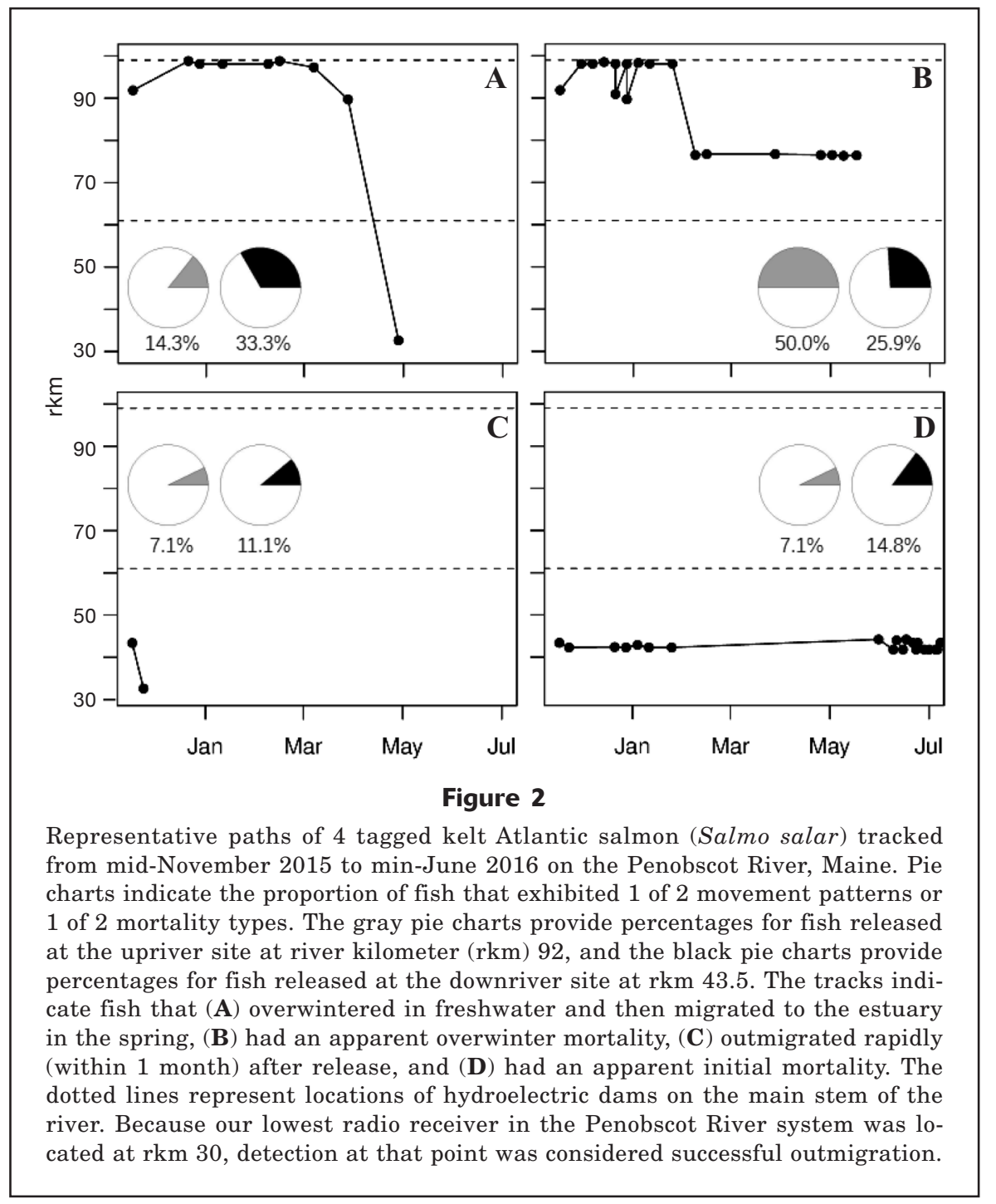

ter fish (i.e. they spent $\geq 2$ years maturing at sea), and because no grilse were tagged, only a limited number of males were available for the project. Total lengths ranged from $720 \mathrm{~mm}$ to $850 \mathrm{~mm}$ (median=770 $\mathrm{mm}$ ). Fish masses ranged from $3.3 \mathrm{~kg}$ to $5.9 \mathrm{~kg}$ (median=4.4 $\mathrm{kg}$ ), and body condition index ranged from -0.33 to 0.16 (median=0.01). Of the 55 fish released, 30 were detected at least once on the stationary radio array, and 49 were detected at least once during mobile tracking. Only three fish were never detected. Over half of all fish $(56 \%)$ were tracked for more than 100 days (median=46 days). On the basis of detection histories (as described in the Materials and methods section) 19 fish from the upriver release and 20 fish from the downriver were included in the survival analysis.

Broadly considered, movement could be classified into 2 major groups overwintering in-system or rapid (within one month) downstream movement to the estuary (Fig. 2). Most of the tagged kelts (46 individuals) overwintered in the Penobscot River, and only 6 rapidly exited the system (Fig. 3). Of the 6 kelts that rapidly exited the system, 4 were initially released at the downriver site ( $\mathrm{rkm}$ 43.5) and two were released at the upriver site (rkm 92). Many of the fish (36 individuals) that remained in the river over the winter made directed upstream movements (Fig. 4). Fish that overwintered in the system did so between rkm 33 and rkm 99, depending on where they were stocked (i.e. under most river conditions Milford Dam at rkm 61 impeded movement upstream). Of these, $15.4 \%$ of the fish were located downstream of the head of tide $(\sim \mathrm{rkm}$ 48), 34.6\% were located between the head of tide and Milford Dam, and the remainder of our tagged fish (50\%) overwintered between Milford Dam and the Piscataquis River confluence within the main stem of the river.

A total of 23 fish moved to the next dam upstream from their release location. Of these fish, 9 made repeated approaches to the dams over a period of days or weeks, indicating that the dams likely impeded their 


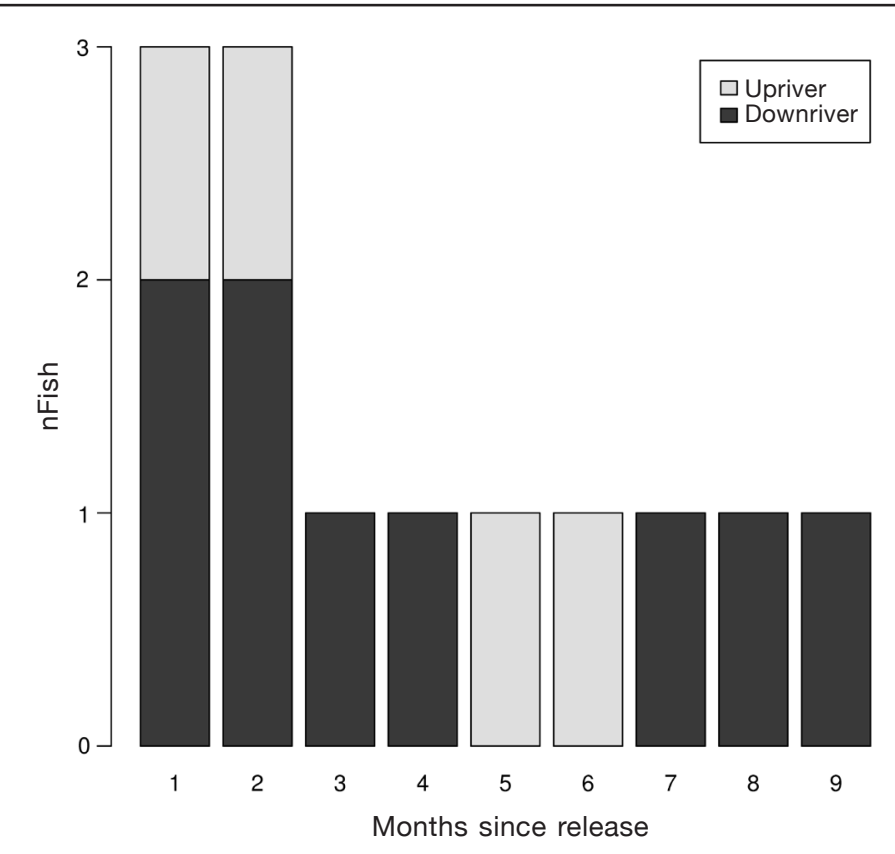

Figure 3

Timing of outmigration (in months after release) of kelt Atlantic salmon (Salmo salar) released in an upriver site (light gray, river kilometer [rkm] 92) and a downriver site (dark gray, rkm 43.5) on the Penobscot River, Maine, on 17 November 2015 and tracked with radio telemetry from release to mid-June 2016. The values on the y-axis represent the number of fish exiting each month.

upstream movement. Apparent overwinter survival was below 50\%; 26 kelts were presumed dead in the river system and an additional 16 fish had an unknown outcome ( 8 from each release group).

The apparent survival for kelts released upriver was $43 \%$. The maximum distance the 28 upper release fish could have moved upstream was $7 \mathrm{~km}$ before reaching the West Enfield Dam. Further movement was possible into the Passadumkeag River for up to $17 \mathrm{~km}$ before reaching the Pumpkin Hill Dam, although because of the absence of roads, this area was not tracked by a mobile receiver, except during our one flight. We found that 13 fish moved upstream from the release site (11 during the first month following release), and 10 of these approached the dam. Half of the fish (14/28) released upstream moved downstream past the Milford Dam. Most fish that successfully passed the dam did so before March, and only one fish descended from the upper river in May. Of the fish in this release group, 4 were documented leaving the system through the estuary, including 2 of those that initially moved upstream (Fig. 3). Of the 16 presumed fish that died in the upriver release group, 6 initially moved upstream, 8 initially moved downstream, and 2 remained within $1 \mathrm{rkm}$ of the release site-a finding that indicated no relationship between initial movement choice and survival. Of the presumed mortalities, 6 occurred after the fish had moved downstream over the Milford Dam. For the purposes of these analyses, mortality and movement are not mutually exclusive (i.e. a fish that was counted as moving upstream could also be counted as a mortality).

The maximum distance that the 27 lower release fish could have moved upstream from the release point in Brewer was $17.5 \mathrm{~km}$ before reaching Milford Dam. Of the 23 fish that moved upstream from the release site; 13 of those approached the dam, and 1 passed the dam during a period of extreme high water in mid-December 2015, when river discharges were more than twice the 113-year median. All upstream movements originating from the downriver release site took place before the end of January. Of these fish 9 were eventually documented leaving the system, including 5 that initially moved upstream (Fig. 3). An additional 10 fish in this release group were presumed dead. Of these fish, 6 moved upstream initially, and 3 remained within $1 \mathrm{rkm}$ of the release site.

A larger proportion of kelts released downriver were observed making directed upstream movements than the proportion of kelts released at the upriver location exhibiting the same behavior ( $85 \%$ vs. $\left.46 \%, \chi^{2}=7.498, \mathrm{df}=1, P=0.006\right)$. There was no difference in apparent survival to the estuary between the upriver and downriver release groups ( $14 \%$ and $33 \%$, respectively, $\chi^{2}=1.8084$, $\mathrm{df}=1, P=0.179)$. Apparent mortality over the course of the study and apparent initial mortality (fish that remained within $1 \mathrm{rkm}$ of the release site for the duration of the study) were not different for the upriver and downriver groups (Table 2). There was no difference in body condition index between the fish that were documented successfully leaving the system, and the fish that were presumed dead (WilcoxonMann-Whitney [W]=367, $P=0.899$ ). There was also no difference in body condition index between the fish that made directed movements upstream and those that moved downstream ( $\mathrm{W}=343, P=0.566)$.

\section{Discussion}

The results of this study suggest that the majority (88\%) of kelts released into the Penobscot River overwinter in freshwater, regardless of where they are released. This finding is consistent with research from the River Teno, where about one third of individuals (35\%) moved directly out to sea (Halttunen et al., 2010). Unlike Halttunen et al. (2013), we found no differences in body condition index between fish that emigrated quickly and fish that overwintered in the Penobscot River. However, our data set of outmigrating fish was considerably smaller than Halttunen et al.'s (13 vs. 166 individuals), the fish spawned artificially in a hatchery rather than naturally in the river, and our outmigrating fish were all females (as opposed to mixed sex in Haltunnen et al. (2013)). 
Research from European rivers suggests that females are generally in better condition than males after spawning, likely because of low instances of aggression among female fish (Halttunen et al., 2013). Because their condition is generally better after spawning, it may be more advantageous for females to remain in the low-productivity, low-risk freshwater environment through the winter (Halttunen et al., 2013) to keep the risk of mortality low for those months, whereas males must enter the marine environment sooner to recondition. In our study, both males were presumed dead. Previous research has also documented low postspawning survival among males, which leads to a higher proportion of iteroparous fish being female (Niemelä et al., 2006; Halttunen et al., 2010). However, given that the sex-ratio of our study fish was so heavily skewed toward females, it is possible that our results are applicable only to female fish. With only 2 male fish (both released at the upriver release, and both mortalities), it is very likely that we were unable to capture the full range of male postspawning behavior.

Unlike the fish in several other studies of kelt movements (Baglinière and Porcher, 1994; Komandina-Douthwright et al., 1997; Cunjak et al., 1998), many fish in our study made directed, upstream movements after release. However, in our study, kelts were released downriver from where they would naturally spawn, if not taken to the hatchery. This provides at least 2 possible reasons why fish would move upstream: to seek more advantageous habitat conditions and because they may have been more physiologically similar to ripe adults than postspawning adults owing to the artificial spawning process at the hatchery.

Further study is needed to clarify the causes of upstream movements, such as those we observed in hatchery-spawned kelts. One possible explanation for upstream movement centers on habitat availability. Estuarine habitat may be most desirable for kelts during severe winters (Cunjak et al., 1998) because of the absence of frazil ice in that area. However, the winter of 2015-16 was unusually mild, which may have contributed to kelts overwintering farther upstream in the watershed during our study. Additionally, studies in other systems (Saunders, 1960; KomandinaDouthwright et al., 1997; Cunjak et al., 1998) have found that habitat complexity (e.g. lakes, large pools, islands, and other structure) was positively correlated with higher instream survival of postspawning fish and higher usage of freshwater habitat instead of marine or estuarine habitat. The first $38 \mathrm{rkm}$ of the Penobscot River are commercially navigable, and relatively few islands (natural or artificial) exist downstream of rkm 48. In contrast, the reach between $\mathrm{rkm} 48$ and rkm 61 is filled with artificial islands built for log drives, as well as several large natural islands. Therefore, for fish released at the downriver site, most of the complex habitat exists upriver of their release point. However, because the habitat between rkm 61 and rkm 99 is mostly complex, braided channel with many small islands, upstream migration would not be necessary for fish released at the upriver location to reach suitable overwintering habitat.

Another possible explanation for upstream migration after release is physiological. In our study, most of the fish in the lower release group and nearly half of the fish in the upper release group made directed movements upstream after release. However, other researchers have found that kelts move downstream after spawning (Baglinière and Porcher, 1994). Upstream movements late in the spawning season, as documented here, have only been documented in fish that were still ripe (Komandina-Douthwright et al., 


\section{Table 2}

Presumed mortality of kelt Atlantic salmon (Salmo salar) released at an upriver and a downriver site on the Penobscot River, Maine, on 17 November 2015 and tracked with radio telemetry from time of release to mid-June 2016. Fish presumed to be initial mortalities are those that remained within $1 \mathrm{~km}$ of their release site for the duration of the study. Fish presumed to be overwinter mortalities are those that remained at a fixed location in the river for several months, including the end of the study in mid-June 2016. Total presumed mortality includes both initial mortalities and overwinter mortalities. Mortality between the two release sites was compared using a chi-square $\left(\chi^{2}\right)$ test.

\begin{tabular}{lccccc}
\hline Mortality & Upriver $(28$ individuals $)$ & Downriver $(27$ individuals $)$ & $\chi^{2}$ & df & $P$ \\
\hline Initial & $2(0.071)$ & $3(0.111)$ & 0.002 & 1 & 0.966 \\
Overwinter & $14(0.500)$ & $7(0.259)$ & 2.432 & 1 & 0.119 \\
Total & $16(0.571)$ & $10(0.370)$ & 1.496 & 1 & 0.221 \\
\hline
\end{tabular}

1997). Because spawning of all the fish in our study was artificially induced in a hatchery, many still had gametes in the abdominal cavity when we surgically implanted tags. Physiological mechanisms to motivate upstream migration before spawning have been noted in previous studies (Bendall et al., 2012), therefore it is possible that our kelts were behaving more like ripe adults than postspawning adults, given that gametes were still present. The majority $(95.3 \%)$ of upstream movements in individuals from both release sites ceased within a month of release. Therefore, without further knowledge of the physiology of each fish, it is difficult to determine a trigger for upstream movement.

Regardless of the mechanism behind upstream movement, the fact that kelts continue to move throughout the fall and early winter may be of concern to river managers. During this time of year, fish passage structures (in both upstream and downstream directions) are typically closed to avoid damage from ice and debris $\left(\right.$ Simpson ${ }^{6}$ ). Keeping these facilities operational in the winter may require substantial expenditures of effort and capital, but may also provide an opportunity for better survival, particularly for kelts moving in a downstream direction.

Because of the logistics of maintaining the radio receiver array, we were unable to place receivers on the Stillwater Branch of the river. Because of this gap in coverage, we were unable to determine the predominant path choice around Marsh Island (rkm 56-63) for fish outmigrating from the upriver release location. In the future, securing access to sites along this portion of the river could help determine whether path choice around the island influences mortality in the lower river. Previous research on Atlantic salmon smolts has shown that downstream passage at hydroelectric facilities results in decreased survival farther downriver (Stich et al., 2015). Because path choice influences the number of dams passed (e.g. there is one dam on the east side of the island and three on the west, Fig. 1),

${ }^{6}$ Simpson, M. 2017. Personal commun. Maine Dep. Mar. Resour., 21 State House Station, Augusta, ME 04333-0021. it may be also be linked to survival. Just as smolts are at risk of being descaled, of movement delays, and depredation at dams, these sites may also pose risks to downstream migrating kelts.

In both release groups, 8 tags were lost to the radio network, and we were unable to ascertain their area of disposition. The lack of transmissions from these tags could be due to a number of factors. First and foremost, the tags were all repurposed from an earlier study of upstream migrating Atlantic salmon, and therefore their batteries had already been somewhat depleted. Additionally, some tags may have been removed from the watershed either by poachers or wildlife (e.g. birds of prey). Finally, the most downriver receiver in the system covered a portion of the river that is inundated with salt water at high tide. Salt water can interfere with radio signals and likely reduced the probability of detection at that receiver during certain time periods.

Survival of kelts released into the Penobscot River was relatively low, compared with survival in European rivers, which may contribute to the observed declines in the number of multispawning individuals in the population (Maynard et al., 2017). Apparent initial mortality (fish that remained within $1 \mathrm{~km}$ of release for the duration of the study) was $<15 \%$ in both release groups. There was no significant difference in apparent overwinter mortality between the groups. Apparent survival to outmigration was at least $23.6 \%$ (13/55 individuals), which is considerably lower than documented survival to outmigration in the River Imsa (65-85\%; Jonsson et al., 1990) in Norway and in the Burrishoole River in Ireland (40\%; Piggins, 1990). Because 2015-2016 was an unusually warm winter, an absence of ice cover on the river may have contributed to low survival because kelts are known to use ice for refuge from aerial predators (Cunjak et al., 1998) such as bald eagles (Willson and Halupka, 1995). Since the initiation of the Penobscot River Restoration Project, the proportion of bald eagle diets made up of marinederived nutrients has been increasing (Call, 2015). Although survival to repeat spawning varies among river systems (2-25\%, Jonsson et al., 1991), multispawning 
returns to the Penobscot River have averaged $0.04 \%$ in the past decade. This percentage is below that of reports from degraded rivers in France where multispawning individuals made up $0.5-3 \%$ of spawning runs (Bardonnet and Baglinière, 2000).

The majority of kelts released into the Penobscot River overwintered in freshwater or the estuary rather than makimg a rapid exit to the marine environment. There was no measurable difference in migratory timing between fish released downstream of the head of tide and those released $\sim 50 \mathrm{~km}$ upstream, and some fish stocked upstream were able to successfully migrate to the ocean through one or two hydroelectric facilities. Survival rates were comparable for the two release groups, but were lower than expected. Additionally, the majority of tagged fish exhibited directed, upstream movements more characteristic of ripe fish than spent fish. Survival and movement patterns may have been influenced by an unusually mild winter. Future research may benefit from a longer time-series of data, as well as better quantification of the reproductive status of the fish. The focus of this study was to document the possibility of adult Atlantic salmon requiring passage both upstream and downstream at dams in the Penobscot River during time periods when these facilities traditionally are nonoperational.

\section{Acknowledgments}

The Penobscot River Restoration Trust, the American Recovery and Reinvestment Act of 2009, the National Marine Fisheries Service, the U.S. Geological Survey, the U.S. Fish and Wildlife Service, and the University of Maine provided funding. C. Domina, D. Buckley, M. Simpson, S. Clark, A. Molina Moctezuma, K. Boyd, R. Spencer, H. Brinson, the Penobscot Indian Nation, the City of Old Town, the Pate family, and the Maine Warden Service provided additional support. This study was performed under the auspices of University of Maine IACUC protocol no. A2014-09-08.

\section{Literature cited}

Baglinière, J. L., and J. P. Porcher.

1994. Les stocks de reproducteurs et le comportement lors de la migration génésique. In Le saumon Atlantique: biologie et gestion de la ressource (J. C. Gueguen and P. Prouzet), p. 101-122. IFREMER, Brest, France.

Bardonnet, A., and J.-L. Baglinière.

2000. Freshwater habitat of Atlantic salmon (Salmo salar). Can. J. Fish. Aquat. Sci. 57:497-506. Article

Bendall, B., A. Moore, D. Maxwell, P. Davison, N. Edmonds, D. Archer, D. Solomon, V. Greest, R. Wyatt, and K. Broad.

2012. Modelling the migratory behaviour of salmonids in relation to environmental and physiological parameters using telemetry data. Fish. Manage. Ecol. 19:475-483. Article
Call, E.

2015. River birds as indicators of change in riverine ecosystems. Ph.D. diss., 129 p. Univ. Maine, Orono, ME.

Chadwick, E. M. P., T. R. Porter, and P. Downton.

1978. Analysis of growth of Atlantic salmon (Salmo salar) in a small Newfoundland river. J. Fish. Res. Board Can. 35:60-68. Article

Cunjak, R. A., T. D. Prowse, and D. L. Parrish.

1998. Atlantic salmon (Salmo salar) in winter: "the season of parr discontent"? Can. J. Fish. Aquat. Sci. 55(S1): 161-180. Article

Ducharme, L. J. A.

1969. Atlantic salmon returning for their fifth and sixth consecutive spawning trips. J. Fish. Res. Board Can. 26:1661-1664. Article

Fay, C., M. Bartron, S. Craig, A. Hecht, J. Pruden, R. Saunders, T. Sheehan, and J. Trial.

2006. Status review for anadromous Atlantic salmon (Salmo salar) in the United States, 294 p. Report by the Atlantic Salmon Biological Review Team to the National Marine Fisheries Service and US. Fish and Wildlife Service. [Available from website.]

Fleming, I. A., and J. D. Reynolds.

2004. Salmonid breeding systems. In Evolution illuminated: salmon and their relatives (A. P. Hendry and S. C. Stearns, eds.), p. 264-294. Oxford Univ. Press, Inc., New York.

Gray, R. W., J. D. Cameron, and A. D. McLennan.

1987. Artificial reconditioning, spawning and survival of Atlantic salmon, Salmo salar L., kelts in salt water and survival of their F1 progeny. Aquac. Fish. Manage. 18:309326. Article

Halttunen, E., A. H. Rikardsen, E. B. Thorstad, T. F. Næsje, J. L. A. Jensen, and Ø. Aas.

2010. Impact of catch-and-release practices on behavior and mortality of Atlantic salmon (Salmo salar L.) kelts. Fish. Res. 105:141-147. Article

Halttunen, E., J. L. A. Jensen, T. F. Næsje, J. G. Davidsen, E. B. Thorstad, C. M. Chittenden, S. Hamel, R. Primicerio, and A. H. Rikardsen.

2013. State-dependent migratory timing of postspawned Atlantic salmon (Salmo salar). Can. J. Fish. Aquat. Sci. 70:1063-1071. Article

Hansen, L. P., and B. Jonsson.

1994. Homing of Atlantic salmon: effects of juvenile learning on transplanted post-spawners. Anim. Behav. 47:220222. Article

Hubley, P. B., P. G. Amiro, A. J. F. Gibson, G. L. Lacroix, and A. M. Redden.

2008. Survival and behaviour of migrating Atlantic salmon (Salmo salar L.) kelts in river, estuarine, and coastal habitat. ICES J. Mar. Sci. 65:1626-1634. Article

Hutchings, J. A., and D. W. Morris.

1985. The influence of phylogeny, size and behaviour on patterns of covariation in salmonid life histories. Oikos 45:118-124.

Jessop, B. M.

1976. Distribution and timing of tag recoveries from native and nonnative Atlantic salmon (Salmo salar) released into Big Salmon River, New Brunswick. J. Fish. Res. Board Can. 33:829-833. Article

Jonsson, B., and N. Jonsson.

2004. Factors affecting marine production of Atlantic salmon (Salmo salar). Can. J. Fish. Aquat. Sci. 61:2369-2383. Article 
Jonsson, N., B. Jonsson, and L. P. Hansen.

1990. Partial segregation in the timing of migration of Atlantic salmon of different ages. Anim. Behav. 40:313321. Article

Jonsson, N., L. P. Hansen, and B. Jonsson.

1991. Variation in age, size and repeat spawning of adult Atlantic salmon in relation to river discharge. J. Anim. Ecol. 60:937-947.

Klemetsen, A., P.-A. Amundsen, J. B. Dempson, B. Jonsson, N. Jonsson, M. F. O'Connell, and E. Mortensen.

2003. Atlantic salmon Salmo salar L., Brown Trout Salmo trutta L. and Arctic Charr Salvelinus alpinus (L.): a review of aspects of their life histories. Ecol. Freshw. Fish 12:1-59. Article

Komandina-Douthwright, S. M., D. Caissie, and R. A. Cunjak. 1997. Winter movement of radio-tagged Atlantic salmon (Salmo salar) kelts in relation to frazil ice in pools of the Miramichi River. Can. Tech. Rep. Fish. Aquat. Sci. 2161, 66 p.

Kusterle, S., E. Halttunen, E. B. Thorstad, T. F. Naesje, J. L. A. Jensen, A. Gallo-Bueno, E. Olague, and A. H. Rikardsen. 2013. The gill maggot Salmincola salmoneus as an indicator of repeat spawning in Atlantic salmon Salmo salar. J. Fish Biol. 82:1068-1073. Article

Lacroix, G. L.

2013. Population-specific ranges of oceanic migration for adult Atlantic salmon (Salmo salar) documented using pop-up satellite archival tags. Can. J. Fish. Aquat. Sci. 70:1011-1030. Article

Legault, C. M.

2005. Population viability analysis of Atlantic salmon in Maine, USA. Trans. Am. Fish. Soc. 134:549-562. Article

Marston, B. H., R. E. Johnson, and S. Power.

2012. Steelhead studies from the Situk River in southeast Alaska, 2002-2008. Alaska Dep. Fish Game, Fish. Data Ser. $12-40,26$ p. [Available from website.]

Maynard, G. A., M. T. Kinnison, and J. D. Zydlewski.

2017. Size selection from fishways and potential evolutionary responses in a threatened Atlantic salmon population. River Research and Applications 33:1004-1015. Article

Nieland, J. L., T. F. Sheehan, and R. Saunders.

2015. Assessing demographic effects of dams on diadromous fish: a case study for Atlantic salmon in the Penobscot River, Maine. ICES J. Mar. Sci. 72:2423-2437. Article

Niemelä, E., J. Erkinaro, M. Julkunen, E. Hassinen, M. Länsman, and S. Brørs.

2006. Temporal variation in abundance, return rate and life histories of previously spawned Atlantic salmon in a large subarctic river. J. Fish Biol. 68:1222-1240. Article

NMFS and USFWS (National Marine Fisheries Service and U.S. Fish and Wildlife Service).

2005. Recovery plan for the Gulf of Maine distinct popu- lation segment of Atlantic salmon (Salmo salar), $268 \mathrm{p}$. National Marine Fisheries Service, Silver Spring, MD. [Available from website.]

Opperman, J. J., J. Royte, J. Banks, L. R. Day, and C. Apse.

2011. The Penobscot River, Maine, USA: a basin-scale approach to balancing power generation and ecosystem restoration. Ecol. Soc. 16(3):7. Article

Parrish, D. L., R. J. Behnke, S. R. Gephard, S. D. McCormick, and G. H. Reeves

1998. Why aren't there more Atlantic salmon (Salmo salar)? Can. J. Fish. Aquat. Sci. 55(S1):281-287. Article

Piggins, D. J.

1990. Annual Report XXXIV. The Salmon Research Trust of Ireland, 34, Newport, Ireland.

Ruggles, C. P.

1980. A review of the downstream migration of Atlantic salmon. Can. Tech. Rep. Fish. Aquat. Sci. 952, 39 p.

Saunders, J. W.

1960. The effect of impoundment on the population and movement of Atlantic salmon in Ellerslie Brook, Prince Edward Island. J. Fish. Res. Board Can. 17:453-473. Article

Saunders, R. L., and C. B. Schom.

1985. Importance of the variation in life history parameters of Atlantic salmon (Salmo salar). Can. J. Fish. Aquat. Sci. 42:615-618. Article

Saunders, R., M. A. Hachey, and C. W. Fay.

2006. Maine's diadromous fish community: past, present, and implications for Atlantic salmon recovery. Fisheries 31:537-547. Article

Seamons, T. R., and T. P. Quinn.

2010. Sex-specific patterns of lifetime reproductive success in single and repeat breeding steelhead trout $(\mathrm{On}$ corhynchus mykiss). Behav. Ecol. Sociobiol. 64:505-513. Article

Spidle, A. P., W. B. Schill, B. A. Lubinski, and T. L. King.

2001. Fine-scale population structure in Atlantic salmon from Maine's Penobscot River drainage. Conserv. Genet. 2:11-24. Article

Stich, D. S., M. M. Bailey, and J. D. Zydlewski.

2014. Survival of Atlantic salmon (Salmo salar) smolts through a hydropower complex. J. Fish Biol. 85:10741096. Article

Stich, D. S., M. M. Bailey, C. M. Holbrook, M. T. Kinnison, and J. D. Zydlewski.

2015. Catchment-wide survival of wild- and hatcheryreared Atlantic salmon smolts in a changing system. Can. J. Fish. Aquat. Sci. 72:1352-1365. Article

Trammell, J. L. J., D. E. Fast, D. R. Hatch, W. J. Bosch, R. Branstetter, A. L. Pierce, J. W. Blodgett, and C. R. Frederiksen.

2016. Evaluating steelhead kelt treatments to increase iteroparous spawners in the Yakima River Basin. North Am. J. Fish. Manage. 36:876-887. Article

Willson, M. F., and K. C. Halupka.

1995. Anadromous fish as keystone species in vertebrate communities. Conserv. Biol. 9:489-497. Article 